\title{
KEJADIAN PREEKLAMPSIA BERDASARKAN POLA MAKAN DAN ANGKA KECUKUPAN GIZI IBU HAMIL
}

\author{
${ }^{1}$ Erni Hernawati, ${ }^{2}$ Mirna Arianti \\ ${ }^{1,2}$ STIKes Rajawali Bandung, Jl. Rajawali Barat No. 73 Bandung \\ 1ernihernawatie@gmail.com; ${ }^{2}$ mirnaariantierga@gmail.com
}

\begin{abstract}
In 2015 the Maternal Mortality Rate in Indonesia was 305 / 100,000 live births and preeclampsia is still one of the factors causing maternal mortality in Indonesia, nutrition intake in pregnant women is one of the predisposing factors for the occurrence of preeclampsia. The aim of this research is aims to describe the incidence of preeclampsia based on diet and Adequacy Rate of Nutrition (AKG) in pregnant women at the Kindergarten II Dustira Hospital, Cimahi City in 2019. This study uses a descriptive method with a cross sectional approach. Samples were taken using simple random technique with a sample of 56 respondents. Data were collected using primary data through interviews with pregnant women using a semi-Food Frequency Questionnaire (FFQ) questionnaire and studied with the $A K G$, and then analyzed using univariate analysis. The results showed that pregnant women with a poor diet, almost half of them had preeclampsia as much as $46.7 \%$ and pregnant women who had a low RDA, most of them were preeclampsia as much as $54.2 \%$. The conclusion of this study is that almost half of pregnant women experience preeclampsia and have a low AKG. Suggestion, prevention of preeclampsia is very important, one of which is by improving the diet of pregnant women in accordance with the Guidelines for Balanced Nutrition.
\end{abstract}

Keywords: nutritional adequacy rate, diet, preeclampsia.

\begin{abstract}
Abstrak - Pada tahun 2015 Angka Kematian Ibu di Indonesia sebanyak 305/100.000 kelahiran hidup dan preeklampsia masih merupakan salah satu faktor penyebab kematian ibu di Indonesia, asupan nutrisi pada ibu hamil menjadi salah satu faktor predisposisi terjadinya preeklampsia. Tujuan dari penelitian ini adalah untuk mengetahui gambaran kejadian preeklampsia berdasarkan pola makan dan Angka Kecukupan Gizi (AKG) pada ibu hamil di Rumah Sakit TK II Dustira Kota Cimahi tahun 2019. Metode yang digunakan dalam penelitian ini adalah deskriptif dengan pendekatan cross sectional. Sampel diambil menggunakan teknik simple random dengan sampel sebanyak 56 responden. Penelitian ini menggunakan data primer melalui wawancara kepada ibu hamil dengan menggunakan kuesioner semi Food Frequency Questionnaire (FFQ) dan dikaji dengan AKG, dan selanjutnya dianalisa menggunakan analisa univariat. Hasil penelitian menunjukkan bahwa ibu hamil dengan pola makan kurang, hampir separuhnya mengalami preeklampsia sebanyak 46,7\% dan ibu hamil yang mempunyai AKG yang kurang sebagian besar preeklampsia sebanyak 54.2\%. Simpulan dari penelitian ini hampir separuhnya ibu hamil mengalami preeklampsia dan mempunyai AKG yang kurang. Saran, pencegahan preeklampsia sangat penting dilakukan salah satunya dengan memperbaiki pola makan ibu hamil yang sesuai dengan Pedoman Gizi Seimbang.
\end{abstract}

Kata Kunci : angka kecukupan gizi (AKG), pola makan, preeklampsia.

\section{PENDAHULUAN}

Mengutip dari data World Health Organization (WHO) United Nations Children's Fund (UNICEF) dan Bank Dunia tahun 2015 bahwa angka kematian ibu hingga saat ini penurunannya masih kurang dari $1 \%$ per tahun. Sebanyak 536.000 perempuan meninggal dunia akibat masalah persalinan. Di negaranegara berkembang kematian ibu merupakan rasio yang tertinggi dengan kasus kematian ibu 450/100.000 kelahiran hidup. Menurut data yang diambil dari Survey Demografi Kesehatan Indonesia (SDKI) Angka Kematian Ibu di Indonesia 
pada tahun 2015 sebanyak 305 per 100.000 kelahiran hidup. Penyebab langsung angka kematian ibu di Indonesia yaitu perdarahan 30\% hipertensi dalam kehamilan (preeklampsia-eklampsia) 27\%, dan infeksi 7\% (Kementrian Kesehatan Republik Indonesia, 2018). Berdasarkan pengertian preeklampsia dapat terjadi pada pada ibu selama kehamilan, sehingga asuhan antenatal harus terfokus pada deteksi dini kemungkinan faktor resiko preeklampsia yang ditandai dengan adanya riwayat preeklampsia sebelumnya, pemeriksaan fisik dan pemeriksaan penunjang. Preeklampsia merupakan komplikasi yang dapat terjadi pada masa kehamilan yang di tandai dengan adanya hipertensi dan proteinuria yang dapat terjadi mulai usia kehamilan >20 minggu. Preeklampsia jika tidak segera mendapat penanganan akan berdampak pada eklampsia bahkan sampai sindroma HELLP (hemolisys, elevated liver enzyme, low platelets count) yang dapat menyebabkan kematian kepada ibu dan janin. Kejadian preeklampsia dapat meningkat pada wanita yang memiliki faktor resiko yaitu, kehamilan gemelli, kelainan vaskularisasi, penyakit ginjal, hipertensi dalam kehamilan, adaptasi kardiovaskular, genetik, riwayat preeklampsia pada kehamilan sebelumnya, obesitas, umur yang beresiko, hiperplasentosis dan faktor nutrisi (Saifuddin, 2016). Preeklampsia menjadi salah satu komplikasi pada masa kehamilan yang dapat dipengaruhi oleh asupan nutrisi ibu hamil. Hal ini dikarenakan pada kasus preeklampsia adanya peningkatan kadar oksidan terutama peroksida lemak, oksidan/radikal bebas didalam tubuh mengalami peningkatan sehingga melebihi kapasitas dalam tubuh untuk menetralkannya yang disebut sebagai stress oksidatif dan menyebabkan disfungsi sel endotel. Mengutip dari Saifudin (2016) pada kondisi preeklampsia membran sel endotel ini lebih mudah mengalami kerusakan, karena letaknya langsung berhubungan dengan pembuluh darah dan mengandung banyak asam lemak tidak jenuh. Asam lemak tidak jenuh sangat rentan terhadap oksidan atau radikal hidroksil, yang akan merubah menjadi perosida lemak. Stress oksidatif ini akan merusak lipid dan protein sel, sehingga dapat menyebabkan preeklampsia. Faktor resiko yang dapat ditimbulkan akibat kekurangan nutrisi atau malnutrisi pada ibu hamil diantaranya preeklampsia, anemia, masalah pada sistem saraf dan efek pada janin diantaranya bayi lahir prematur, berat bayi lahir rendah, gangguan pertumbuhan dan perkembangan otak pada janin, gangguan sistem syaraf dan cacat bawaan lahir (Varney, 2007). Melalui studi pendahuluan yang dilakukan di Rumah Sakit Dustira TK II pada Januari 2019. Preeklampsia masih merupakan penyebab angka kesakitan pada ibu hamil, bersalin maupun nifas di Rumah Sakit TK II Dustira. Kasus preeklampsia pada tahun 2016 sebanyak 276/1.783 kelahiran hidup dengan persentase $15,4 \%$ atau rata-rata perbulannya terdapat 23 orang yang mengalami preeklampsia. Pada tahun 2017 kasus preeklampsia mengalami penurunan sebanyak 193/1.884 kelahiran hidup dengan presentase $10,2 \%$ atau ratarata perbulannya 17 orang. Persentase penurunan kasus preeklampsia sebesar 5,2\%. Sementara pada tahun 2018 kasus preeklampsia mengalami peningkatan kembali yaitu sebanyak 237/1.792 kelahiran hidup dengan persentase $13,2 \%$ atau rata-rata perbulannya 20 orang yang mengalami preeklampsia. Penelitian ini bertujuan untuk mengetahui kejadian preeklampsia berdasarkan pola makan dan 
angka kecukupan gizi pada ibu hamil di Rumah Sakit TK II Dustira kota Cimahi tahun 2019

\section{METODE PENELITIAN}

Metode yang digunakan dalam penelitian ini adalah metode deskriptif dengan pendekatan pendekatan cross sectional. Melalui penelitian ini hendak diketahui gambaran kejadian preeklampsia berdasarkan pola makan dan AKG pada ibu hamil di Rumah Sakit TK II Dustira kota Cimahi tahun 2019. Variabel dalam penelitian ini terdapat pola makan dan AKG pada ibu hamil sebagai variabel independen dan kejadian preeklampsia sebagai variabel dependen. Teknik pengambilan sampel menggunakan simple random sampling. Sampel yang digunakan dalam penelitian ini sebanyak 56 responden yang masuk kedalam kriteria inklusi. Kriteria inklusi yang ditetapkan

dalam penelitian ini yaitu ibu hamil usia kehamilan >20 minggu yang datang untuk memeriksakan kehamilannya ke Ruang Kebidanan Rumah Sakit TK II Dustira. Kriteria ekslusi yaitu Ibu hamil usia kehamilan >20 minggu dengan preeklampsia disertai dengan komplikasi kehamilan lainnya seperti diabetes melitus, hipertensi kronik dan hipertensi gestasional. Data ini diambil menggunakan data primer yaitu dengan melakukan wawancara kepada responden melalui kuesioner Semi Food Frequency Questionnaire (FFQ) untuk melihat pola makan dan AKG. Data yang sudah diperoleh dari responden selanjutnya diolah dengan menggunakan excel dan di analisa menggunakan analisa univariat.

\section{HASIL PENELITIAN}

Tabel 1. Distribusi Frekuensi Preeklampsia pada Ibu Hamil

\begin{tabular}{|c|c|c|c|}
\hline \hline No & Preeklampsia & Frekuensi & Persentase \\
\hline 1. & Ya & 18 & $32,1 \%$ \\
\hline 2. & Tidak & 38 & $67,9 \%$ \\
\hline & Total & 56 & $100,0 \%$ \\
\hline
\end{tabular}

Tabel 1 menunjukan bahwa hampir separuhnya terdapat ibu hamil dengan preeklampsia sebanyak 32,1\%.

Tabel 2. Distribusi Frekuensi Pola Makan pada Ibu Hamil

\begin{tabular}{|c|c|c|c|}
\hline No & Pola Makan & Frekuensi & Persentase \\
\hline 1. & Kurang & 30 & $53,6 \%$ \\
\hline 2. & Baik & 32 & $46,4 \%$ \\
\hline & Total & 56 & $100,0 \%$ \\
\hline
\end{tabular}

Tabel 2 menunjukan bahwa sebagian besar ibu hamil memiliki pola makan yang kurang sebanyak 53,6\%.

Tabel 3. Distribusi Frekuensi Angka Kecukupan Gizi (AKG) pada Ibu Hamil

\begin{tabular}{|c|c|c|c|}
\hline No & AKG & Frekuensi & Persentase \\
\hline 1. & Kurang & 24 & $42,9 \%$ \\
\hline 2. & Cukup & 32 & $57,1 \%$ \\
\hline & Total & 56 & $100,0 \%$ \\
\hline
\end{tabular}

Tabel 3 menunjukan bahwa hampir separuhnya ibu hamil memiliki AKG yang kurang sebanyak $42,9 \%$. 
Tabel 4. Tabel Silang Preeklampsia Berdasarkan Pola Makan pada Ibu Hamil

\begin{tabular}{|c|c|c|l|l|}
\hline \multicolumn{1}{c}{ Pola Makan } & \multicolumn{1}{c}{ Preeklampsia } & \multicolumn{1}{l}{ Total } \\
\hline No & & Ya & Tidak & \\
\hline 1. & Kurang & $\begin{array}{l}14 \\
(46,7 \%)\end{array}$ & $\begin{array}{l}16 \\
(53,3 \%)\end{array}$ & $\begin{array}{l}30 \\
(100,0 \%)\end{array}$ \\
\hline 2. & Baik & 4 & 22 & 26 \\
& & $(15,4 \%)$ & $(84,6 \%)$ & $(100,0 \%)$ \\
\hline Total & & 18 & 38 & 56 \\
& & $(32,1 \%)$ & $(67,9 \%)$ & $(100,0 \%)$ \\
\hline
\end{tabular}

Tabel 4 menunjukan bahwa ibu hamil yang mempunyai pola makan kurang, hampir separuhnya mengalami preeklampsia sebanyak $46,7 \%$, begitupun dengan ibu yang mempunyai pola makan baik sebagian kecil yang mengalami preeklampsia sebanyak $15,4 \%$.

Tabel 5. Tabel Silang Preeklampsia Berdasarkan AKG pada Ibu Hamil

\begin{tabular}{|c|c|c|c|c|}
\hline \multirow[t]{2}{*}{ No } & \multirow{2}{*}{ AKG } & \multicolumn{2}{|c|}{ Preeklamp sia } & \multirow{2}{*}{ Total } \\
\hline & & $\mathrm{Ya}$ & Tidak & \\
\hline 1. & Kurang & $\begin{array}{l}13 \\
(54,2 \%)\end{array}$ & $\begin{array}{l}11 \\
(45,8 \%)\end{array}$ & $24(100,0 \%)$ \\
\hline 2. & Cukup & $\begin{array}{l}5 \\
(15,6 \%)\end{array}$ & $\begin{array}{l}27 \\
(84,4 \%)\end{array}$ & $\begin{array}{l}32 \\
(100,0 \%)\end{array}$ \\
\hline & Total & $\begin{array}{l}18 \\
(32,1 \%)\end{array}$ & $\begin{array}{l}38 \\
(67,9 \%)\end{array}$ & $\begin{array}{l}56 \\
(100,0 \%)\end{array}$ \\
\hline
\end{tabular}

Tabel 5 menunjukan bahwa ibu hamil yang mempunyai AKG yang kurang, sebagian besar mengalami preeklampsia sebanyak $54,2 \%$, begitupun dengan ibu yang mempunyai AKG cukup sebagian kecil yang mengalami preeklampsia sebanyak $15,6 \%$.

\section{PEMBAHASAN}

Berdasarkan hasil data menunjukan bahwa dari total responden terdapat ibu hamil dengan preeklampsia sebanyak (32.1\%). Angka ini menunjukan bahwa masih adanya morbiditas pada ibu dan janin yang disebabkan oleh preeklampsia ditandai juga dengan sebagian besar ibu hamil dengan preeklampsia yang menjadi responden penelitian di Rumah Sakit Dustira menjalani perawatan konservatif yaitu sebanyak 10 orang (55.5\%). Data di atas sejalan dengan teori yang dikemukakan oleh Saifuddin (2016) yang menyatakan bahwa hipertensi dalam kehamilan/ preeklampsia merupakan 5$15 \%$ penyulit dalam kehamilan dan merupakan salah satu dari tiga penyebab tertinggi mortalitas dan morbiditas pada ibu bersalin. Di Indonesia mortalitas dan morbiditas yang disebabkan oleh hipertensi/preeklampsia masih cukup tinggi. Hal ini terkait dengan etiologi tidak jelas, oleh perawatan dalam persalinan masih ditangani oleh petugas non medik dan sistem rujukan yang belum sempurna seperti pemilihan faskes yang terbatas, dan rumah sakit dengan fasilitas yang terbatas.

Hal ini sejalan dengan data menurut Kemenkes RI (2018) yang menyebutkan bahwa penyebab secara langsung AKI di Indonesia yaitu perdarahan $30 \%$, hipertensi dalam kehamilan (preeklampsia-eklampsia) 27\%, dan infeksi 7\%. Sedangkan berdasarkan penelitian yang dilakukan oleh Chalid (2016) mengemukakan bahwa preeklampsia menjadi penyebab langsung kematian yang kedua setelah perdarahan, tetapi menjadi fokus utama dalam upaya menurunkan kematian ibu, preeklamsia dapat dicegah dengan pelayanan antenatal terfokus. Deteksi kemungkinan resiko preeklampsia dapat dilakukan di fasilitas 
kesehatan layanan primer dan bila ditemukan tanda-tanda keadaan ibu hamil semakin memburuk segera rujuk ke fasilitas kesehatan selanjutnya. Berdasarkan penelitian menunjukan bahwa masih adanya morbiditas pada ibu dan janin yang disebabkan oleh preeklampsia ditandai juga dengan sebagian besar ibu hamil atau sebanyak 10 orang $(55.5 \%)$ mengalami preeklamsia. Hal ini sesuai dengan teori yang dikemukakan oleh Saifuddin (2016) yang menyatakan bahwa tingginya mortalitas dan morbiditas ibu bersalin salah satunya disebabkan oleh preeklampsia. Di Indonesia mortalitas dan morbiditas yang disebabkan oleh preeklampsia masih cukup tinggi. Tingginya mortalitas dan morbiditas disebabkan selain oleh etiologi tidak jelas, juga oleh perawatan dalam persalinan masih ditangani oleh petugas non medik dan sistem rujukan yang belum sempurna seperti pemilihan faskes yang terbatas, dan rumah sakit dengan fasilitas yang terbatas.

Pola makan merupakan gambaran mengenai asupan makanan berdasarkan jenis, frekuensi dan banyaknya yang dikonsumsi setiap harinya. Dalam penelitian ini untuk melihat pola makan ibu hamil menggunakan kuesioner semi food frequency questionnaire (FFQ) yang mencakup jenis, frekuensi dan jumlah makanan yang dikonsumsi dalam jangka waktu perhari, perminggu, sampai 1 bulan. Selanjutnya dihitung skornya untuk melihat kekerapan konsumsi pangan. Hal ini sejalan dengan pernyataan yang dikemukakan oleh Sirajuddin (2018) mengenai survey konsumsi pangan. Survey konsumsi pangan merupakan serangkaian kegiatan pengukuran konsumsi makanan pada individu, keluarga dan kelompok masyarakat. Sirajuddin mengungkapkan hal ini bisa dilakukan dengan menggunakan metode pengukuran yang sistematis, menilai asupan zat gizi dan mengevaluasi asupan zat gizi sebagai cara penilaian status gizi secara tidak langsung. Terdapat beberapa metode survei konsumsi pangan untuk konsumsi kelompok diantaranya: metode semi frekuensi makan (food frequency questionnaire), metode frekeunsi makan (food frequency questionnair) neraca bahan makanan (food balance sheet) metode jumlah makanan (food account).

Hasil penelitian menunjukan bahwa beberapa hal yang berpengaruh terhadap kurangnya pola makan pada ibu hamil salah satunya yaitu tidak beragamnya makanan yang dikonsumsi dan porsi makan yang masih sama dengan saat dia belum hamil. Hal penelitian diatas sejalan dengan dengan teori yang dikemukakan oleh Kementerian Kesehatan Republik Indonesia (KEMENKES RI) tahun 2014 dalam pedoman gizi seimbang yaitu agar ibu hamil mendapatkan gizi yang baik selama kehamilannya, setiap harinya ibu hamil harus mengkonsumsi lima kelompok pangan atau setiap kali makan. Makanan pokok, lauk-pauk, sayuran, buah-buahan dan minuman adalah komponen lima kelompok pangan yang harus dikonsumsi ibu hamil setaip hari. Mengkonsumsi lebih dari satu jenis untuk setiap kelompok makanan (makanan pokok, lauk pauk, sayuran dan buahbuahan) setiap kali makan akan lebih baik.

Berdasarkan hasil penelitian terdapat beberapa hal yang mempengaruhi kurangnya asupan nutrisi pada ibu hamil diantaranya: porsi makan yang masih sama dengan saat dia belum hamil, tidak beragamnya makanan yang dikonsumsi oleh ibu hamil, masih adanya ibu hamil yang masih mempercayai beberapa pantangan jenis makanan yang tidak boleh dikonsumsi oleh ibu hamil seperti 
semangka karena mereka berasumsi bahwa mengkonsumsi semangka bisa menyebabkan air ketuban lebih banyak dari seharusnya dan makanan lainnya seperti timun karena akan menyebabkan banyak keputihan pada ibu hamil, Ibu hamil yang sejak awal tidak suka mengkonsumsi sayuran dan ibu hamil yang tidak suka mengkonsumsi susu.

Hal ini sejalan dengan pernyataan yang dikemukakan oleh Fathonah (2016) bahwa status sosial ekonomi, lingkungan, tingkat pengetahuan, kebudayaan, dan dukungan keluarga sangat mempengaruhi kebiasaan konsumsi pangan ibu hamil setiap harinya. Hal ini sejalan dengan hasil penelitian yang sudah dilakukan oleh Juariah (2018) yaitu beberapa ibu hamil masih memiliki kepercayaan dan praktik budaya pada masa kehamilan dengan pantangan beberapa jenis makanan yang tidak boleh dikonsumsi oleh ibu hamil yang mempengaruhi asupan nutrisi pada ibu hamil.

Berdasarkan hasil penelitian bahwa sebagian besar ibu hamil yang mempunyai pola makan dan AKG yang kurang mengalami preeklampsia. Hal ini sesuai dengan pernyataan yang dikemukakkan oleh Saifuddin (2016) bahwa salah satu faktor resiko preeklampisa adalah nutrisi, hal ini dikarenakan ibu hamil dengan preeklampsia telah terbukti bahwa kadar oksidan, khususnya peroksida lemak meningkat, sedangkan antioksidan, misal vitamin $\mathrm{E}$ menurun sehingga terjadi dominasi kadar oksidan peroksida lemak yang relatif tinggi. Peroksida lemak sebagai oksidan/radikal bebas yang sangat toksis ini akan beredar dalam aliran darah dan akan merusak sel endotel. Membran sel endotel lebih mudah mengalami kerusakan oleh peroksida lemak, karena letaknya langsung berhubungan dengan aliran darah dan mengandung banyak asam lemak tidak jenuh. Asam lemak tidak jenuh sangat rentan terhadap oksidan radikal hidroksil, yang akan berubah menjadi peroksida lemak.

Berdasarkan hasil penelitian di ketahui bahwa sebagian besar ibu hamil dengan preeklampsia mengalami kurang asupan nutrisi buah-buahan dan sayursayuran yang mengandung antioksidan tinggi. Beberapa penelitian mengungkapkan bahwa buah atau sayur yang mengandung antioksidan tinggi dapat mencegah kerusakan sel endotel pada pembuluh darah sebagai etiologi preeklampsia. Hal ini sesuai dengan pernyataan yang dikemukakan oleh Fathonah (2016) yaitu kandungan terbesar buah dan sayuran adalah vitamin A, C dan E dikenal sebagi vitamin antioksidan yang mampu meningkatkan kesehatan. Salah satu cara untuk menurunkan tekanan darah yaitu dengan mengkonsumsi buah dan sayur secara teratur. Konsumsi buah dan sayur dianjurkan minimal dua porsi sehari lebih kurang 200 gram bagian yang dapat dimakan. Tidak ada batasan untuk konsumsi buah dan sayur ibu hamil bisa mengkonsumsinya setiap hari dan sebaiknya menempati porsi terbesar sekitar 60-70\% dalam susunan menu makan, tidak seperti pada zat gizi lainnya seperti protein karbohidrat dan lemak yang ada batasan konsumsinya.

Hal ini sejalan dengan penelitian yang telah dilakukan oleh Nofrisa (2010) yang mengemukakan bahwa ibu hamil dengan preeklampsia memiliki defisiensi vitamin $\mathrm{C}$ dan vitamin $\mathrm{A}$, dibandingkan dengan ibu hamil yang tidak preeklampsia, sedangkan ibu defisiensi vitamin E antara ibu preeklampsia dan tidak preeklampsia tidak memiliki perbedaan.

Berdasarkan hasil penelitian diketahui bahwa separuh ibu hamil dengan preeklampsia mengalami kurang asupan 
kalsium dan vitamin D yang terdapat pada susu dan yoghurt. Hal ini sesuai dengan pernyataan yang dikemukakan oleh Fathonah (2016) yaitu asupan kalsium yang adekuat pada ibu hamil sekitar 350 $\mathrm{mg} / \mathrm{hari}$ berperan penting dalam pencegahan preeklampsia pada ibu hamil. Menurut Lowdermilk (2013) mengemukakan susu dan yoghurt merupakan sumber makanan yang kaya akan kalsium menyediakan sekitar 300 mg per cangkir $(240 \mathrm{ml})$ namun banyak wanita hamil yang tidak mengkonsumsi makanan ini atau tidak mengkonsumsi dalam jumlah yang cukup untuk memenuhi asupan kalsium yang direkomendasikan sebanyak $600 \mathrm{mg} / \mathrm{hari}$. Asupan kalsium yang adekuat pada ibu hamil berhubungan dengan penurunan resiko hipertensi/preeklampsia pada ibu hamil. Sedangkan konsumsi vitamin D berperan penting dalam absorpsi dan metabolisme kalsium dalam tubuh.

Hal ini mengkonfirmasi hasil penelitian yang dikemukakkan oleh Kurniasari, (2017) yaitu terdapat hubungan yang signifikan antara kekurangan kalsium dalam darah ibu hamil dengan kejadian preeklampsia.

Bersadarkan hasil penelitian diketahui bahwa separuh ibu hamil preeklampsia banyak mengkonsumsi makanan yang mengandung natrium tinggi seperti udang, keju, kecap, donat, bolu, dan risoles. Hal ini sesuai dengan pernyataan yang dikemukakan oleh Lowdermilk (2013) yaitu asupan natrium yang berlebih tidak diperbolehkan selama kehamilan, karena dapat berperan dalam terjadinya hipertensi/preeklampsia pada orang yang sensitif garam. Asupan yang direkomendasikan pada wanita hamil, menyusui ataupun wanita tidak hamil diperkirakan sebesar 1,5 gr/hari atau jangan melebihi 2,3 gr/hari. 2,3 gr natrium terkandung dalam garam sebanyak sebanyak satu sendok teh (6 gr). Menurut Fathonah (2016) asupan kalsium yang tinggi pada bahan makanan alami maupun suplemen dapat mencegah preeklampsia akibat natrium. Natrium akan dikeluarkan melalui urin sebaliknya konsumsi tinggi natrium akan memaksa keluarnya kalsium melalui urin. Hal ini tidak sejalan dengan penelitian yang dilakukan oleh Febriana (2017) yang mengemukakan bahwa tidak ada hubungan yang signifikan antara asupan natrium dengan kenaikan tekanan darah pada ibu hamil.

Berdasarkan penelitian sebagian kecil ibu hamil preeklampsia mengkonsumsi kafein yang terdapat di kopi dan coklat. Hal ini sesuai dengan pernyataan yang dikemukakan oleh Lowdermilk (2013) yaitu efek buruk yang dapat ditimbulkan oleh konsumsi kafein pada ibu hamil yaitu dapat menyebabkan vasokontriksi pada pembuluh darah sehingga memicu terjadinya preeklampsia dan gangguan suplai nutrisi ke janin sehingga menjadi salah satu etiologi terjadinya pertumbuhan janin terhambat. Hal ini tidak sejalan dengan hasil penelitian yang dilakukan oleh Regi (2017) yang mengemukakan bahwa tidak terdapat hubungan yang signifikan antara asupan kafein dengan kenaikan darah sistolik dan diastolik pada ibu hamil. Menurut hasil penelitian yang dilakukan oleh Carolia (2016) mengemukakan bahwa terdapat salah satu meningkatkan kualitas hidup seseorang.

\section{SIMPULAN DAN SARAN}

Kesimpulan dari penelitian ini yaitu hampir separuh ibu hamil yang mempunyai pola makan kurang mengalami preeklampsia dan sebagian besar ibu hamil yang mempunyai AKG yang kurang mengalami preeklampsia. 
Merujuk kepada kesimpulan ini disarankan kepada seluruh ibu hamil untuk menjaga pola makan dengan baik untuk mencegah komplikasi pada kehamilan salah satunya untuk mencegah kejadian preeklampsia dengan cara mengkonsumsi makanan yang mengandung kalsium dan vit D yang terdapat pada susu yoghurt dan sereal, banyak mengkonsumsi buah dan sayur, dan mengurangi konsumsi makanan yang mengandung natrium tinggi seperti garam, keju, saos dan kecap. Untuk itu diharapkan kepada petugas kesehatan di RS Dustira kota Cimahi dapat melakukan promosi kesehatan ibu hamil melalui pendidikan kesehatan mengenai pola makan dan AKG selama kehamilan.

\section{DAFTAR PUSTAKA}

Arikunto, S. 2009. Prosedur Penelitian Suatu Pendekatan Praktik. Jakarta: Rineka Cipta.

Carolia, N. dan Luh, G. I. A. 2016. Coklat Hitam untuk Mencegah Preeklampsia Pada Kehamilan. [Online]. volome 5, (1) halaman 5962Tersedia:http://juke. kedokteran.unila.ac.id/index./majori ty/article/download/981/709 [ 08 Agustus 2019].

Cunningham, F.G. et al. 2014. Obstetri Wiliams 23rd edition vol 2. Jakarta: EGC.

Fathonah, S. 2016. Gizi \& Kesehatan untuk Ibu Hamil. Jakarta: Erlangga.

Febriana, E. et al. 2017. Hubungan Asupan Natrium, Kalsium Dan Magnesium Dengan Tekanan Darah Pada Ibu Hamil Trimester II Dan III (Studi Di Wilayah Kerja Puskesmas
Bulu Kabupaten Temanggung). Dalam Jurnal Kesehatan Masyarakat (ejournal). [Online],vol 5 (4) halaman 648-655. Tersedia:https://ejournal3.undip.ac.i d/index.php/jkm/article/viewFile/18 733/17811 [ 31 Januari 2019].

Hartono, R. et al. 2017. Hubungan Asupan Energi dan Gizi Makro serta Status Gizi pada Pasien Preeklampsia di RSIA Siti Fatimah Kota Makassar. [Online], halaman 43-49. Tersedia: http://journal.ipm2kpe.or.id/index.p hp/JKS/article /view/83 [25 Juli 2019].

Kementrian Kesehatan Republik Indonesia. 2014. Pedoman Gizi Seimbang. Jakarta: Kemenkes RI.

Kementrian Kesehatan Republik Indonesia. 2018. Data dan Informasi Profil Kesehatan Indonesia. Jakarta: Kemenkes RI.

Kurniasari, D. et al. 2017. Hubungan Kadar Kalsium Dalam Darah Ibu Hamil dengan Kejadian Preeklampsia di RSUD H Abdul Moeloek Bandar Lampung [Online], vol 6 nomor 4 halaman 202-207 Tersedia:

http://www.ejurnalmalahayati.ac.id/ index.Php/duniakesmas/article/view I501 [ 31 Januari 2019].

Kosasih dan Parramatra Vip. 2020. Peningkatan Kualitas Pelayanan Kesehatan dan Pengaruhnya Terhadap Peningkatan Kepuasan Pasien di Puskesmas [online], Halaman:. Tersedia: 
https://jurnal.1ldikti4.or.id/index.php /jurnalsoshum/article/view/223

Lowdermilk, D.L. et al. 2013. Buku Keperawatan Maternitas. 8th edition Buku 1. Jakarta: PT Salemba Medika.

Mutia, N. et al. 2010. Kurang Asupan Vitamin A, C, E, dan Beta Karoten Meningkatkan Kejadian Preeklampsia di RSUD Sardjito Yogyakarta. Universitas Gadjah Mada. [Online], vol 33 (2) halaman 136-142.

Tersedia:https://ejournal.persagi.org /index.php/Gizi_Indon/article/view/ 91[14 Januari 2019].

Nuryani. et al. 2013. Hubungan Pola Makan, Sosial Ekonomi, Antenatal Care, dan Karakteristik Ibu Hamil dengan Kasus Preeklampsia di Kota Makassar. Universitas Hassanudin Makassar. Dalam Media Gizi Masyarakat Indonesia [Online], vol 2 (2) halaman 104-112 Tersedia: http://repository.unhas.ac.id/handle/ 123456789/8683 [ 31 Januari 2019].

Paramitasari, T.F. dan Santi, M. 2012. Hubungan Antara Gaya Hidup selama Masa Kehamilan dan Kejadian Preeklampsia. Universitas Airlangga Surabaya. Dalam The Indonesian Journal of Public Health [Online], vol 8 (3) halaman 122-125. Tersedia:

http://journal.unair.ac.id/downloadf ull/PH5972546d769a35fullabstract. pdf[31 Januari 2019].

Pribadi, A. et al. 2015 . Kehamilan Risiko Tinggi. Jakarta: CV Sagung Seto.
Saifuddin, AB. 2016. Ilmu Kebidanan Sarwono Prawihardjo. 1nd edition Cet 5. Jakarta; PT Bina Pustaka Sarwono Prawihardjo.

Sirajuddin. et al. 2018. Bahan Ajar Gizi Survey Konsumsi Pangan. Jakarta: Kementrian Kesehatan Republik Indonesia.

Varney, H. et al. 2007. Buku Ajar Asuhan Kebidanan. 4th edition Vol 1. Jakarta: EGC. 